\title{
sciendo

\section{In-Situ Moisture Assessment in External Walls of Historic Building using Non-Destructive Methods}

\author{
Ritvars FREIMANIS ${ }^{1 *}$, Rasa VAISKUNAITE ${ }^{2}$, Tereza BEZRUCKO ${ }^{3}$, Andra BLUMBERGA $^{4}$ \\ ${ }^{1,3,4}$ Institute of Energy Systems and Environment, Riga Technical University, \\ Azenes iela 12/1, Riga, LV-1048, Latvia \\ ${ }^{2}$ Department of Environmental Protection and Water Engineering, Vilnius Gediminas Technical \\ University, Sauletekio al. 11, Vilnius, LT-10223, Lithuania
}

\begin{abstract}
In-situ measurements of a case study building located in Riga old town near the river Daugava has been carried out in this work. Performed measurements are moisture level of historic masonry, and interstitial monitoring of temperature and relative humidity between the layers of internal insulation and external wall. Obtained results are compared with outdoor weather data. Results show that during the cold months of the year no rising damp problem. No interstitial condensation under the internal insulation, and no risk of mold growth occur. However, the façade of the building tends to be highly influenced by the outdoor weather, and the moisture of the masonry increases during the rain load events.
\end{abstract}

Keywords - Dielectric measurement; internal insulation; interstitial relative humidity; masonry deterioration; microwave measurement; wind-driven rain

\section{INTRODUCTION}

High greenhouse gas emissions rate is driving climate change. One of the main causes is high energy demand from existing building stock [1], [2]. In Europe, historic buildings still account for as many as 24 to $35 \%$ of the entire building stock. Moreover, the building stock of historic buildings composes from 27 to $42 \%$, of the final energy demand in Europe - depending on the country [3]. It is estimated that about $36 \%$ of $\mathrm{CO}_{2}$ emissions in the European Union (EU) comes from the building sector [4], [5].

The main reasons for the high energy consumption in the buildings depends on the physical elements, thermal properties and climate conditions [6]. The main reason for high energy consumption in historic buildings is poor thermal properties of the building envelope, in terms of high thermal transmittance or U-Value. In theory U-value can be calculated if the thermal conductivity of the material and boundary conditions are known, but in reality, this value can be influenced by moisture, cracks, etc. [7]. Nevertheless, moisture-caused problems are present in many historic buildings, that leads to degradation of building materials, unsuitable indoor air conditions and poor thermal properties of exterior walls [8]. Unhealthy indoor air quality can affect general senses of the human, reducing their work abilities and leading to health risks [9]. Jimenez-Besecos et al. in their research, concluded, that healthy indoor air quality (IAQ) can be achieved when retrofit of a historic building is done. Healthy IAQ in the study is defined as 19 to $20{ }^{\circ} \mathrm{C}$ temperature, 40 to $70 \%$ relative humidity and $\mathrm{CO}_{2}$ concentration below $1000 \mathrm{ppm}$ [10].

As most of the thermal energy losses are through the opaque building envelope (exterior walls), insulation of exterior walls, can reduce energy consumption of the building and thereby reduce

\footnotetext{
* Corresponding author.

E-mail address: ritvars.freimanis_1@rtu.lv
}

(C2019 Ritvars Freimanis, Rasa Vaiskunaite, Tereza Bezrucko, Andra Blumberga.

This is an open access article licensed under the Creative Commons Attribution License (http://creativecommons.org/ 
greenhouse gas emissions [11]. External walls can be insulated either from the outside or from the inside. To avoid exacerbation of moisture-related problems in the building, it is recommended to insulate the building from the outside. But almost in all cases insulation of historic buildings from the outside is not possible due to preservation of heritage value of the historic façade, or other limitations, such as space restrictions. Therefore internal insulation of exterior walls becomes the single best solution to reduce energy consumption of the historic building and thereby reduce greenhouse gas emissions [11]. At the same time, the renovation should not compromise the structural integrity and indoor air quality of the renovated building.

If the masonry moisture content exceeds $3 \%$ of mass moisture content, there is a need to undertake action in order to reduce this moisture content before the renovation [12]. Moreover, if moisture sources in the masonry are not eliminated, further renovation is not recommended, considering masonry decay and other moisture-caused problems will reappear in a short period of time [8]. However, the situation that only one moisture source is present in the historic building is very rare, and many factors affecting the moisture content in the masonry makes it hard to clearly distinguish among the main moisture sources in the historic building. Therefore, to find a non-harmful renovation method a hygrothermal performance and moisture content of a historic masonry must be assessed. And to avoid oversized, inadequately expensive and ineffective interventions, preliminary monitoring of a building is recommended [13]. There are six main groups of moisture sources in the buildings: Raising dump, Wind-driven rain, Built-in moisture, Hygroscopic phenomena, Surface condensation, Damages in water systems, i.e. piping and gutter [14].

With new non-destructive moisture assessment technologies emerging and improving for moisture content assessment in-situ, the measurements are becoming more applicable to historic buildings, cause destructive methods such as drilling holes and inserting probes are mostly not preferable in historic facades. Test results obtained in-situ through the systematic surveys can be very helpful for the moisture source determination [8].

The main goal of this research is to study the application of internal insulation in historic buildings by assessing the possible moisture sources in the external wall and their impact on moisture content and moisture transport in the wall.

\section{MATERIALS AND METHODS}

\subsection{Case Study Building}

The case study building at Biskapa gate 6 in Riga, Latvia was selected for the in-situ measurements. This particular building was selected, because of complaints from building residents about the discomfort, in the form of increased indoor humidity levels. Another reason for choosing this building was the visible deterioration of the façade (Fig. 1). 


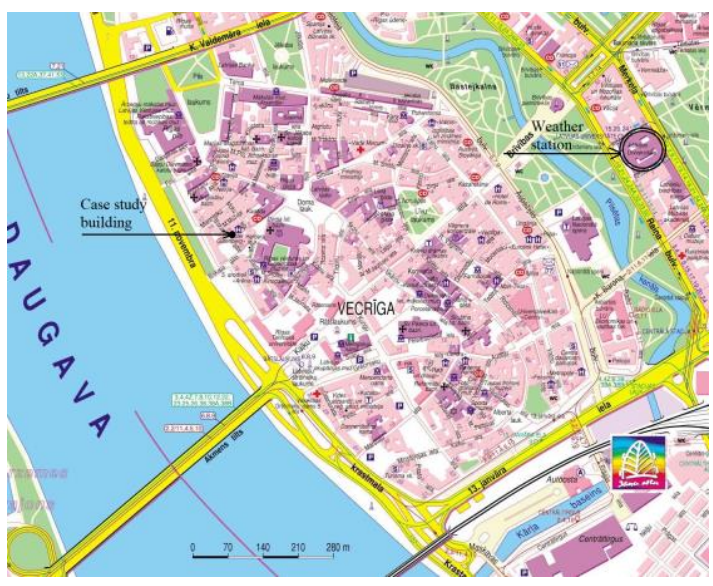

a)

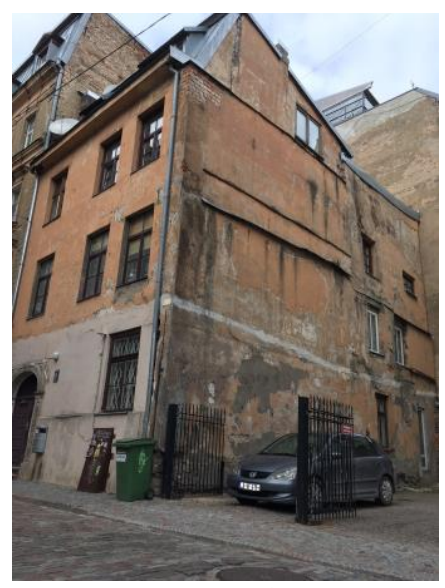

b)

Fig. 1. Case study at Biskapa gate 6: a) location of building and weather station in map; b) façade of the building [15].

The building is a three-story residential building with additional attic floor and one underground floor (basement). Building was built in 1880 and is located in the historic center of Riga, approximately $150 \mathrm{~m}$ from the river Daugava (Fig. 1). The building area is $120.9 \mathrm{~m}^{2}$ with a $1511 \mathrm{~m}^{3}$ of construction volume. The building has two adjacent buildings, one on the North-West (NE) and another on the North-East (NE) side of the building. Both adjacent buildings are 1 story higher than the case study building. The South-West (SW) side of the building is the main façade, with the entrance from the street (Biskapa gate). The SE facing façade is the largest open area to the outdoor weather, such as wind driven rain, sun radiation and wind. The free space between the SE façade and next building in this direction is 15 meters, this adjacent building has the same height as the case study building. About 10 years ago the ground floor flat owner has installed internal insulation of glasswool $(0.05 \mathrm{~m})$ on the SE wall.

\subsection{Methodology}

Qualitative and quantitative methods have been used for determination of the possible moisture sources in the external wall masonry.

Qualitative analysis includes direct observation of the building to identify existing signs of decay and moisture caused damages.

Quantitative method includes moisture distribution evaluation of the building exterior wall in relative scales. Moisture of the wall was measured from the outside. Wall moisture measurements from the inside were limited due to applied internal insulation. The moisture assessment was carried out in two depths $-2 \mathrm{~cm}$ and $20 \mathrm{~cm}$ deep in the masonry (including plaster). For these measurements a multifunction measuring device Trotec T3000 was used [16]. Trotec T3000 was used with two types of measurement probes for different measurement depths:

- Dielectric probe TS 660 SDI for $2 \mathrm{~cm}$ depth;

- Microwave probe TS 610 SDI for $20 \mathrm{~cm}$ depth.

Dielectric and microwave probe are both used for moisture distribution measurements in relative scale and cannot be directly compared with each other. Meaning that the same readings from both probes does not indicates same moisture contents.

For monitoring purposes, the measured South-East facing wall was divided into smaller squares forming a grid, approximately $0.4 \mathrm{~m}$ to $0.4 \mathrm{~m}$ each (Fig. 4). The same grid was used for the repeated moisture measurements over a period of time. Wall moisture measurements were started 
in the autumn (September $21^{\text {st }}$ of 2018) and were continued until the spring (March $5^{\text {th }}$ of 2019). During the monitoring period, wall moisture was measured 5 times.

From the interior side of the wall, the monitoring system was installed, floor plan showing the measurement points are presented in Fig. 2.

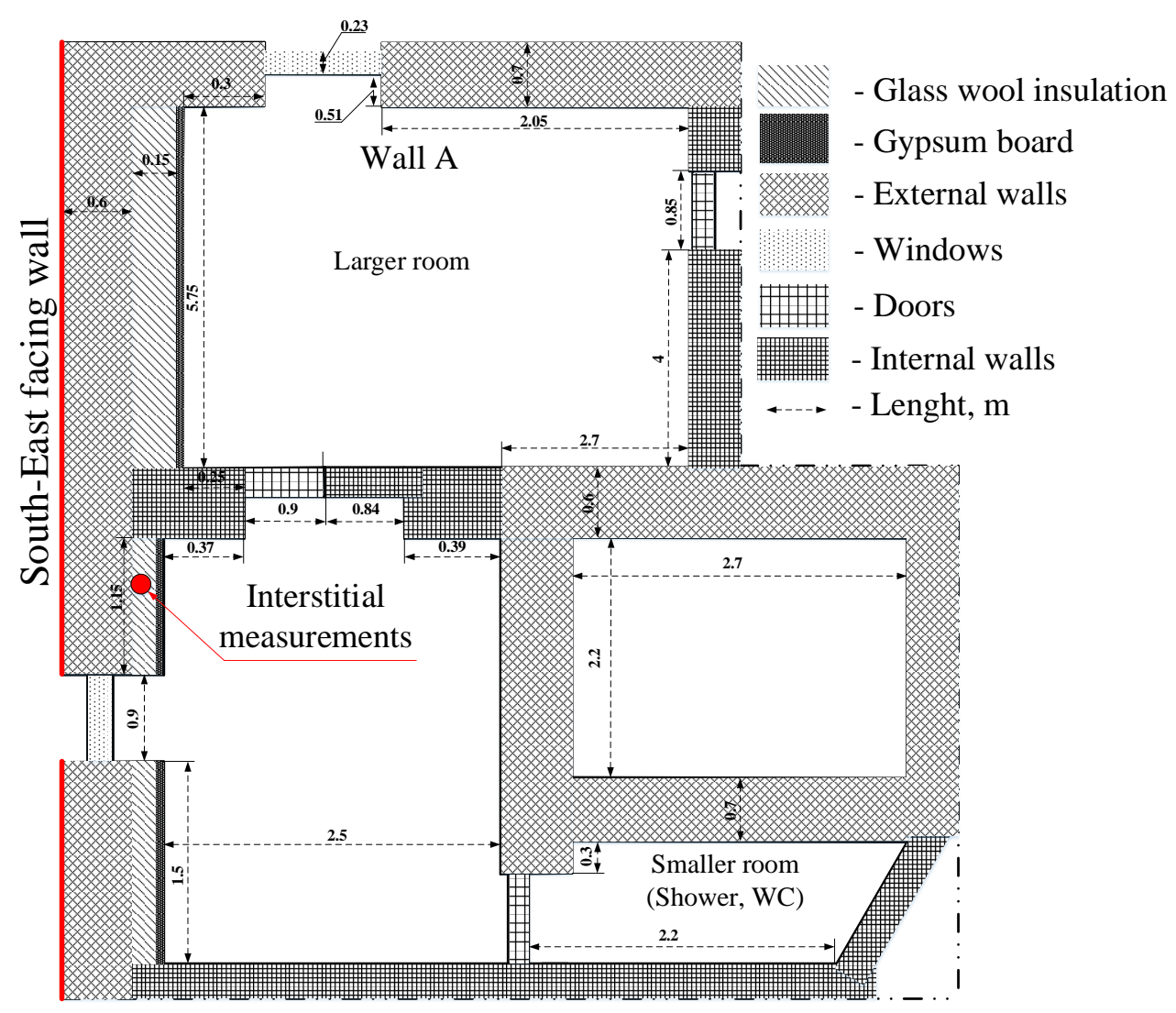

Fig. 2. Cross section of monitored wall with measurement points.

The monitoring system started to collect data on $20^{\text {th }}$ November 2018 . Monitoring system included relative humidity and temperature monitoring in between the layers of the insulation of the external wall. Monitoring of the relative humidity and temperature in between the layers of the insulation was done using the Honeywell HIH 4000-002 and type T PFA insulated twin twisted pair thermocouple cable. Data logger Campbell CR 1000 was used for data logging of these sensors. For the insertion of the monitoring system, a small hole with a diameter of $27 \mathrm{~mm}$ was drilled in the internally insulated wall. In total, two relative humidity and two temperature sensors were installed in the insulation layers. The sensors were installed in pairs (relative humidity sensor combined with temperature sensor). The sensor pairs were installed $20 \mathrm{~cm}$ below the hole, one pair between the wall and insulation and the other pair between the insulation and gypsum board. Additionally, temperature and relative humidity was measured near the interior surface of the insulated wall. After the insertion of the relative humidity and temperature sensors, the hole was refilled with mineral wool and gypsum board. To avoid extra moisture addition to the insulation system through the cut and to retain access to the sensors, no plaster was used to cover the hole. 
Instead the gypsum board was sealed in place with masking tape, and additionally covered with vapor tight aluminium adhesive tape.

Weather data from the closest weather station were used. The weather station is located at the University of Latvia (Fig. 1) and the data are managed by the "Latvian Environment, Geology and Meteorology Centre" (LEGMC) [17].

\section{Results AND Discussions}

Visual inspection of the façade revealed severe material loss, i.e. plaster and reduced masonry thickness at the ground level. Moreover, multiple cracks and poor-quality craftsmanship was noticeable. Algae growth was also evident on some parts of the façade. However, no sign of efflorescence was noticed. There was also an observation of some repair jobs carried out, where some of the lost material (plaster, bricks) had been replaced with cement. Near the ground level on the west-facing wall, a loss of building material was observed. Material loss was most severe on the edges of the wall and under the window but was almost undetectable on the front facing wall (Fig. 3).

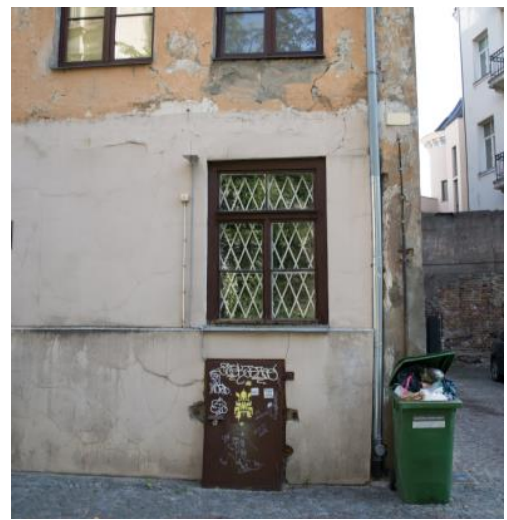

a)

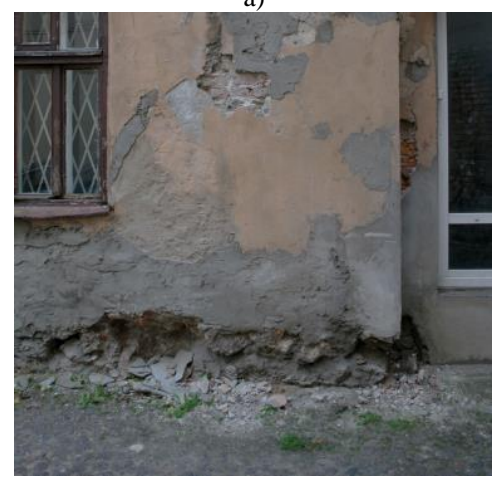

c)

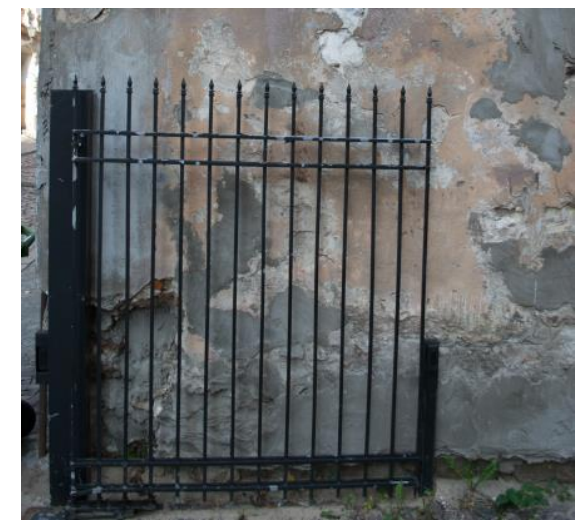

b)

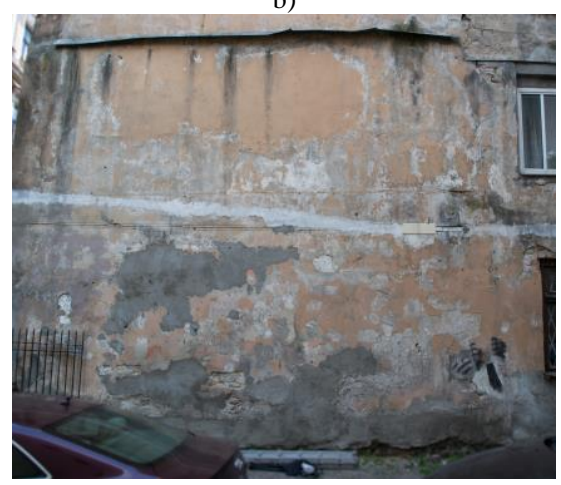

d)

Fig. 3. Façade of the building: a) South-West façade; b) South corner; c) right corner of South-East façade; d) South-East façade.

Fig. 4 shows the moisture measurements for both the $2 \mathrm{~cm}$ and $20 \mathrm{~cm}$ depths. The obtained values indicate moisture in relative scale, from drier to more wet area, where 0 signifies the most-dry and 250 the most-wet value. 


\begin{tabular}{|c|c|c|c|c|c|c|c|c|c|c|c|c|c|c|c|c|c|c|c|}
\hline \multirow{3}{*}{\multicolumn{2}{|c|}{$\begin{array}{l}134 \\
131\end{array}$}} & \multicolumn{2}{|c|}{ - Тор } & \multicolumn{3}{|c|}{ - Middle } & & & \multicolumn{11}{|c|}{ - Bottom } \\
\hline & & 147 & 149 & 128 & 125 & 159 & 181 & 155 & 147 & 82 & 128 & 153 & 168 & & & 142 & 116 & 82 & 143 \\
\hline & & 146 & 149 & 148 & 120 & 186 & 170 & 164 & 155 & 110 & 124 & 124 & 118 & & & 130 & 96 & 92 & 140 \\
\hline 250 & 183 & 77 & 161 & 183 & 134 & 185 & 126 & 143 & 128 & 144 & 124 & 137 & 138 & & & 80 & 97 & 130 & 129 \\
\hline 225 & 184 & 130 & 151 & 173 & 137 & 172 & 161 & 129 & 176 & 175 & 187 & 111 & 94 & & & 92 & 127 & 139 & 166 \\
\hline 200 & 168 & 168 & 164 & 150 & 150 & 159 & 130 & 131 & 158 & 159 & 140 & 147 & 146 & 118 & 75 & 95 & 98 & 99 & 105 \\
\hline 175 & 152 & 132 & 105 & 141 & 153 & 116 & 134 & 131 & 139 & 175 & 160 & 155 & 158 & 111 & 108 & 126 & 147 & 133 & 104 \\
\hline 150 & \multicolumn{19}{|c|}{$2 \mathrm{~cm}$ depth } \\
\hline 125 & 52 & 45 & 45 & 52 & 39 & 43 & 45 & 67 & 63 & 38 & 44 & 34 & 47 & & & 37 & 52 & 41 & 43 \\
\hline 100 & 57 & 47 & 47 & 44 & 33 & 55 & 79 & 59 & 67 & 33 & 52 & 35 & 53 & & & 54 & 57 & 54 & 57 \\
\hline 75 & 64 & 48 & 48 & 54 & 45 & 44 & 80 & 61 & 74 & 65 & 47 & 53 & 63 & & & 54 & 46 & 32 & 43 \\
\hline 50 & 60 & 57 & 57 & 62 & 39 & 42 & 47 & 54 & 75 & 38 & 61 & 30 & 65 & & & 64 & 56 & 46 & 69 \\
\hline 25 & 63 & 72 & 72 & 76 & 61 & 41 & 53 & 57 & 58 & 65 & 44 & 55 & 52 & 35 & 47 & 68 & 44 & 37 & 49 \\
\hline 0 & 50 & 43 & 43 & 55 & 64 & 52 & 40 & 41 & 56 & 72 & 50 & 60 & 58 & 50 & 47 & 70 & 55 & 40 & 36 \\
\hline
\end{tabular}

Fig. 4. Moisture distribution in the wall, March $5^{\text {th }}$, year 2019.

The average moisture values for $20 \mathrm{~cm}$ depth of the external wall of all the measurement dates are presented in Table 1 . The measurement difference between highest and lowest measured value varies from 45 in November to 65 in February.

TABle 1. AVERage Values of 20 CM DePTH Measurements

\begin{tabular}{llllll}
\hline & $21^{\text {st }}$ September & $22^{\text {nd }}$ November & $19^{\text {th }}$ January & $12^{\text {th }}$ February & $5^{\text {th }}$ March \\
\hline Average & 48.35 & 48.56 & 49.24 & 50.45 & 52.30 \\
Max value & 79 & 78 & 83 & 89 & 80 \\
Min value & 28 & 33 & 30 & 24 & 30 \\
Mode & 39 & 50 & 44 & 49 & 47 \\
Median & 48 & 47 & 48 & 49 & 52 \\
Standard & 10.85 & 9.46 & 9.18 & 11.28 & 11.41 \\
deviation & 19 & & & & \\
\hline
\end{tabular}

TABle 2. AVERAge VAlues of 2 CM DePth MEASUREMENTS

\begin{tabular}{llllll}
\hline & $21^{\text {st }}$ September & $22^{\text {nd }}$ November & $19^{\text {th }}$ January & $12^{\text {th }}$ February & $5^{\text {th }}$ March \\
\hline Average & 99.84 & 123.95 & 107.12 & 119.58 & 137.59 \\
Max value & 182 & 190 & 161 & 161 & 187 \\
Min value & 49 & 13 & 14 & 16 & 75 \\
Mode & 126 & 126 & 100 & 125 & 147 \\
Median & 99 & 126 & 108.5 & 126 & 139 \\
Standard & 28.87 & 30.98 & 26.44 & 21.21 & 26.99 \\
deviation & & & & & \\
\hline
\end{tabular}

For better understanding of moisture distribution in the wall and how it corresponds to the changing weather, the measurement area was divided in three sections (Fig. 7). The sections are 
bottom section from ground up to $0.8 \mathrm{~m}$, middle section from $0.8 \mathrm{~m}$ to $1.6 \mathrm{~m}$ and top section from $1.6 \mathrm{~m}$ to $2 \mathrm{~m}$.

In Fig. 5 changes of average values in top, middle and bottom sections, for $20 \mathrm{~cm}$ depth measurements are presented. There has been an upward trend at the bottom section of the wall, during the measurement period. Likewise, the top section follows the upward trend, with the slight decrease from $1^{\text {st }}$ to $2^{\text {nd }}$ measurement. The moisture measurements of the middle section had a drop of average moisture value in January, but afterwards they start to follow an upward trend.

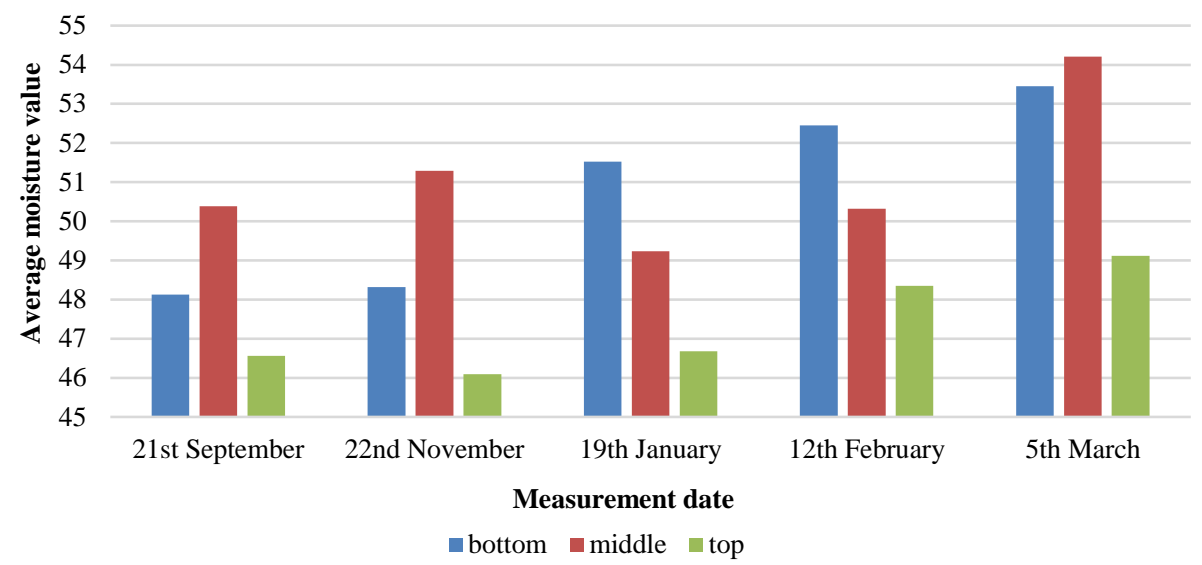

Fig. 5. Average moisture value changes for $20 \mathrm{~cm}$ depth measurements.

In Fig. 6 changes of average values in top, middle and bottom sections, for $2 \mathrm{~cm}$ depth measurements are illustrated. The $2 \mathrm{~cm}$ depth measurements follow a very similar trend as the $20 \mathrm{~cm}$ depth measurements in the middle section, with an increase in the period from the September to November, followed by a drop and then continuing an upward trend.

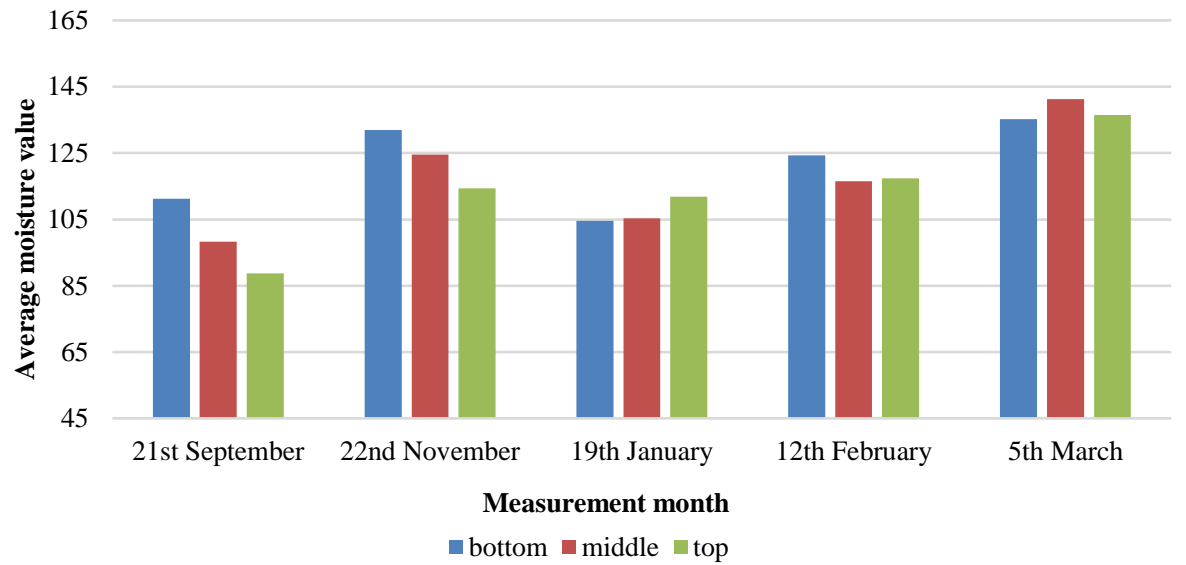

Fig. 6. Average moisture value changes for $2 \mathrm{~cm}$ depth measurements.

In Fig. 7 the average moisture measurement values are compared to each other and to average relative humidity period of 24-hours, prior to the measurements. It can be seen that $2 \mathrm{~cm}$ depth measurements, that represent moisture values near the surface, are more than two times greater 
than $20 \mathrm{~cm}$ depth measurements that represent moisture values $20 \mathrm{~cm}$ inside the masonry. During the measurement period, average $20 \mathrm{~cm}$ depth measurements change only by 3.5 during the whole period, but maintain the upward trend. $2 \mathrm{~cm}$ depth measurements on the other hand fluctuate and change by a total of 37.75 during the measurement period.

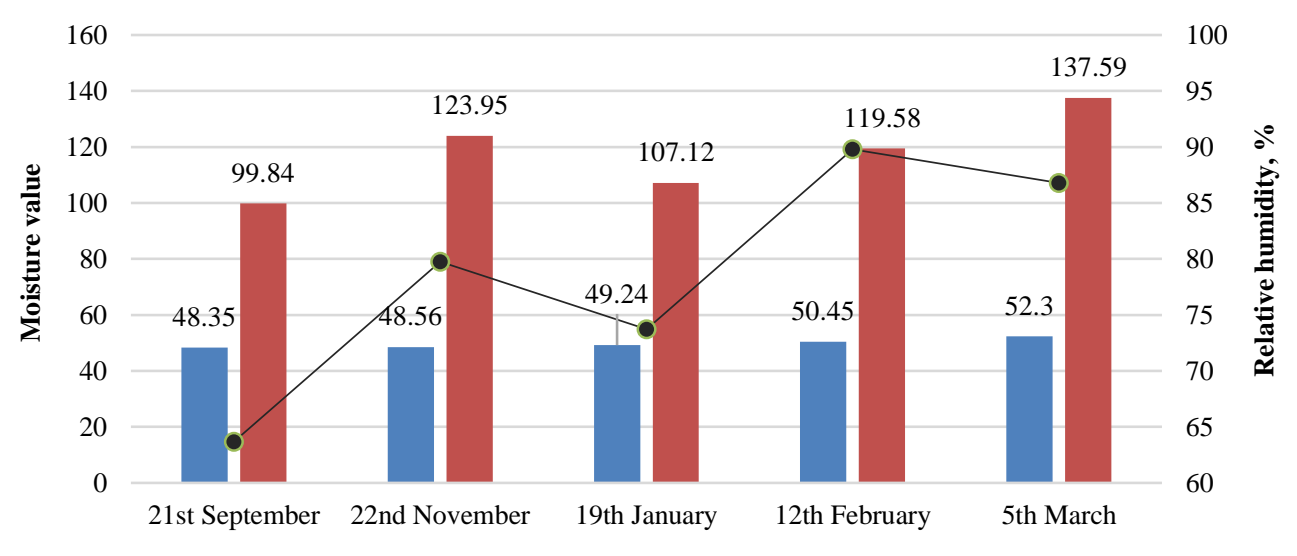

\section{Months}

$20 \mathrm{~cm}$ depth $2 \mathrm{~cm}$ depth $-\bullet$ Average Relative humidity of $24 \mathrm{~h}$ prior to the measurements

Fig. 7. Average values of the wall moisture measurements and outdoor relative humidity

In Fig. 8 the correlation between the outdoor relative humidity and wall moisture is presented. The correlation observed is good for $2 \mathrm{~cm}$ depth and little less for $20 \mathrm{~cm}$ depth.

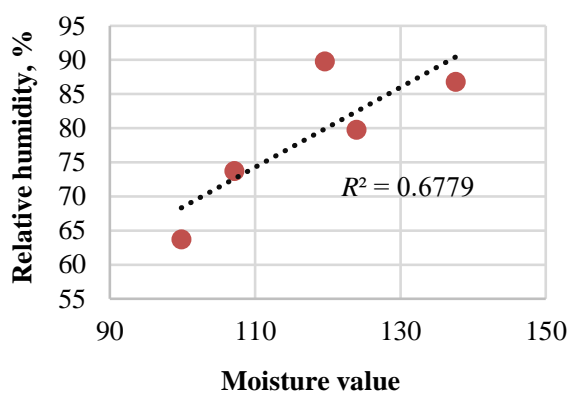

a)

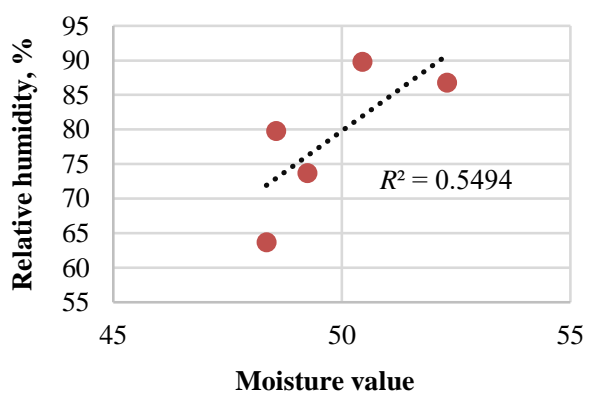

b)

Fig. 8. Correlation between outdoor relative humidity and: a) $2 \mathrm{~cm}$ depth measurement values; b) $20 \mathrm{~cm}$ depth measurement values.

Rain load events with the total amount of rain $1 \mathrm{~mm}$ or greater are shown in Fig. 9. Total rain event is greater between $1^{\text {st }}$ and $2^{\text {nd }}$ measurement, than between the $2^{\text {nd }}$ and $3^{\text {rd }}$ measurements. That could explain the sudden drop of average moisture values in the $3^{\text {rd }}$ measurements (in $19^{\text {th }}$ January). Moreover, the $4^{\text {th }}$ and $5^{\text {th }}$ measurements, that have shown the highest average moisture values, are made right after the rain event. 


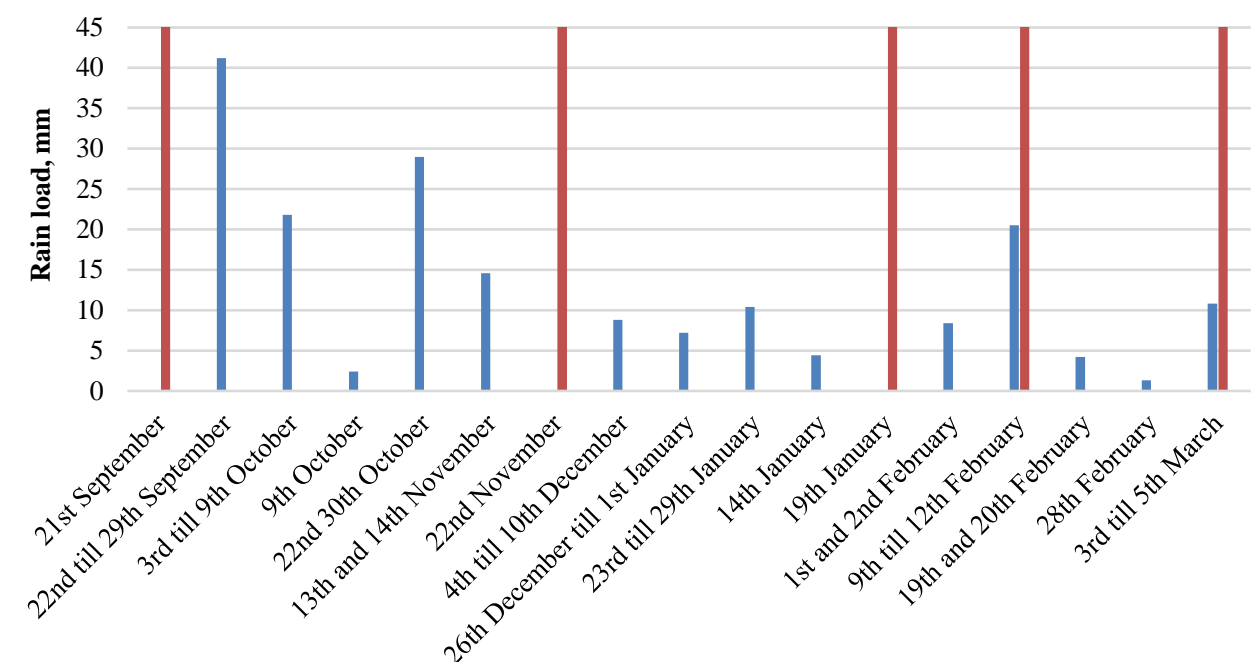

Rain event (at least 1mm)

$\square$ Rain load $\quad$ Measurement date

Fig. 9. Rain load event during the monitoring period.

24-hour cumulative rain events of three consecutive days prior to the measurements are presented in Fig. 13. When comparing Fig. 7 with Fig. 10, it can be seen that on the $12^{\text {th }}$ February when the total rain load is higher (by $9.5 \mathrm{~mm}$ ), the average $2 \mathrm{~cm}$ depth measurement is slightly lower (by 18.01) than on March $5^{\text {th }}$. However, the rain load during March $5^{\text {th }}$ is higher (by $4.9 \mathrm{~mm}$ ) than on February 12. After comparing average moisture values of $2 \mathrm{~cm}$ depth measurements with the rain event from Fig. 10, it can be seen that the average moisture value is affected more by the rain load event 24-hours before the measurement, rather than total rain load event of the 3-day period prior to the measurement.

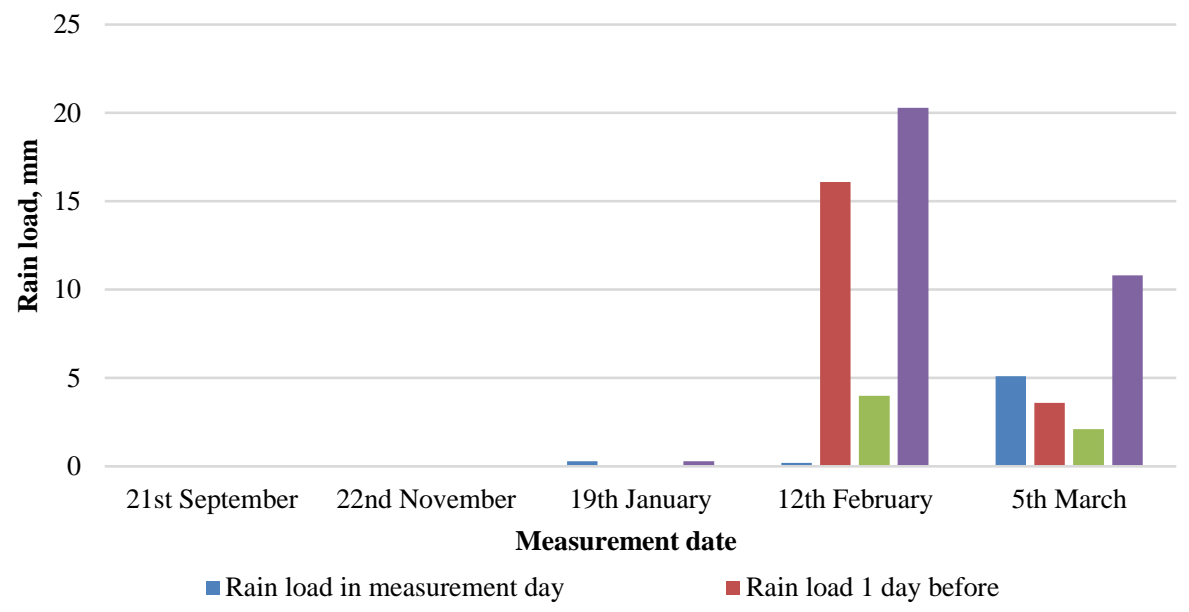

Fig. 10. Rain load of three days prior to the measurement. 
The dominant winds and wind speeds during the monitoring period are shown in Fig. 11. Over the period of three days prior to the measurements on $12^{\text {th }}$ February and $5^{\text {th }}$ March, the following wind conditions were observed:

- $12^{\text {th }}$ February $58.46 \%$ of wind comes from the South, followed by $13.58 \%$ from SouthWest with a dominant speed of $5 \mathrm{~m} / \mathrm{s}$;

- $5^{\text {th }}$ March $47.69 \%$ of wind comes from the South west followed by $18.6 \%$ from South, with a dominant speed of 3 to $5 \mathrm{~m} / \mathrm{s}$.

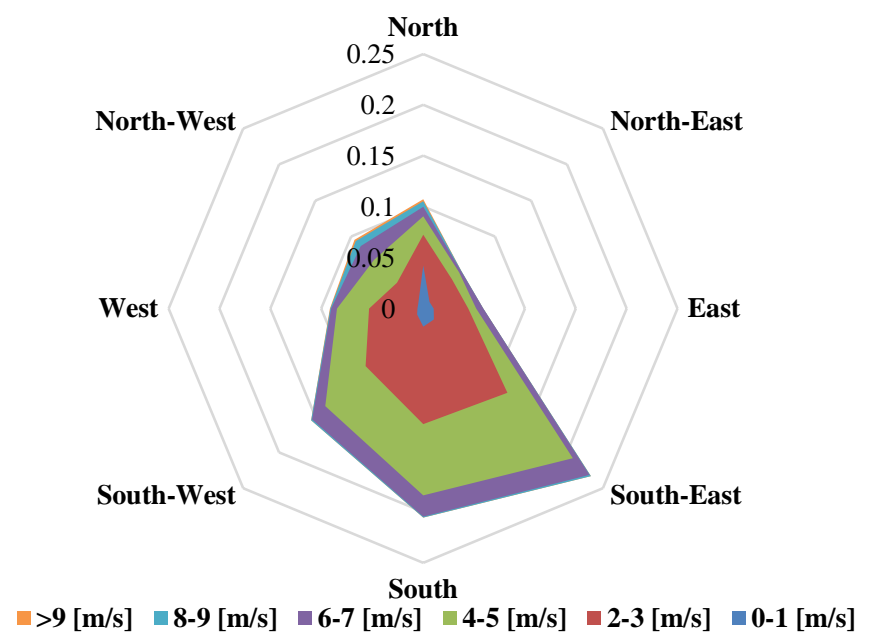

Fig. 11. Wind direction and speed during the monitoring period.

Fig. 12 present relative humidity and temperature measurements during the monitoring period. It can be seen that relative humidity under the insulation material stays mainly below $80 \%$ that has been considered as the critical moisture when the mold growth would occur. Relative humidity fluctuates during the monitoring period from $58.85 \%$ to $83.9 \%$ and on the average is $74 \%$. It also can be seen that temperature under the insulation material stays above $0{ }^{\circ} \mathrm{C}$ that reduces the risks of freeze thaw cycles to occur. During the monitoring period temperature fluctuates from $5^{\circ} \mathrm{C}$ to $11.5^{\circ} \mathrm{C}$ and on the average is $8.4{ }^{\circ} \mathrm{C}$.

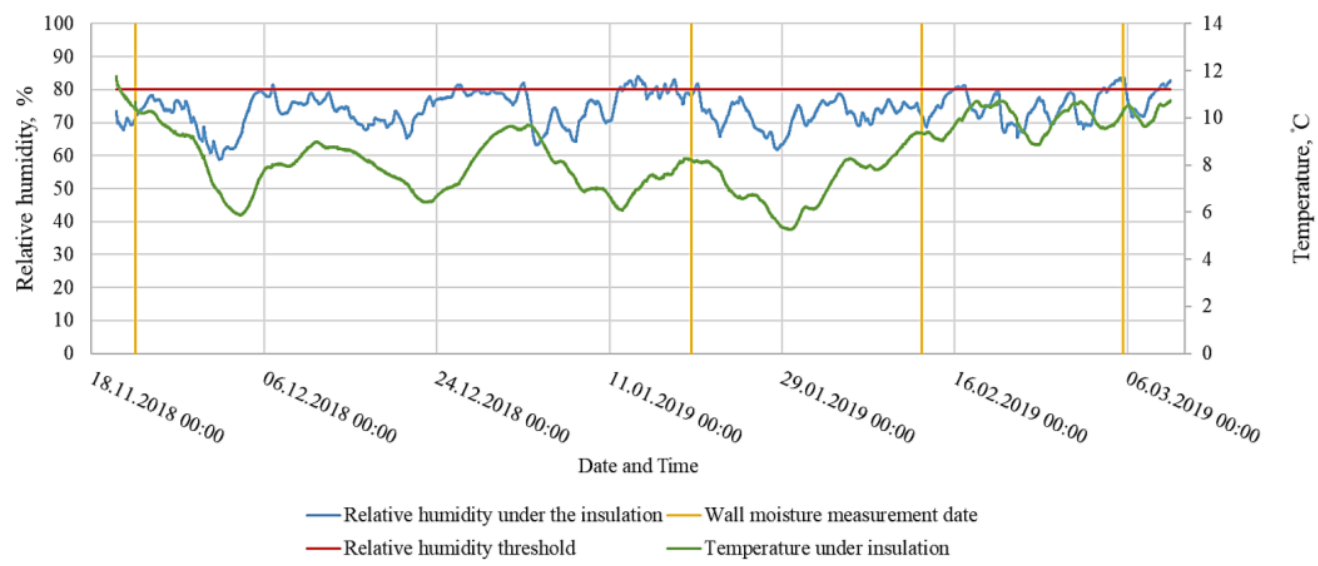

Fig. 12. Relative humidity in the insulation system. 


\section{Conclusions}

The main goal of this research is to study application of internal insulation in historic buildings by assessing the possible moisture sources in the external wall and their impact on moisture content and moisture transport in the wall.

Obtained results show the loss of external plaster is obvious in many areas of the façade, combined with cracks, and cuts. These open areas allow outdoor moisture i.e. wind driven rain, to easily penetrate the wall. Algae growth on the façade indicates that rain water has been present on the walls' surface.

Measurement results also show that moisture content is building up during the autumn and winter periods. This is strongly influenced by outdoor moisture, both relative humidity and rain load events. The dominating wind during the monitoring period was from the same direction as the assessed façade is facing (SE), indicating that wind driven rain could be the reason for the accumulation of moisture in the masonry.

Outdoor weather conditions also have an effect on the interstitial conditions between the layers of the insulation and the external wall. But no interstitial condensation has been observed during the monitoring period. Highest relative humidity beneath the insulation material during the monitoring period reaches $84 \%$ and for most of the time relative humidity stays under $80 \%$. Such moisture conditions do not cause high risk of mold growth. Results from biological assessment of insulation sample taken from the wall show no signs of mold presence.

No clear signs of rising damp problem were observed during the monitoring period. But as the monitoring period took place only seven months in the cold period of the year, rising damp problem could still be a problem during the spring and warm months of the year.

It must be considered that the non-homogeneity of the façade could be the reason for the fluctuations of the measurements, especially the $2 \mathrm{~cm}$ depth measurements close to the surface.

For more conclusive results, monitoring should be continued for at least one full year. Wind driven rain measurements on the façade and continuous moisture monitoring at different heights of the masonry will be performed.

\section{ACKNOWLEDGEMENT}

This research is funded by the Ministry of Economics of the Republic of Latvia, project "Improvement of building energy efficiency technologies", project No. VPP-EM-EE-2018/1-0003.

\section{REFERENCES}

[1] Policy Pathways Modernising Building Energy Codes. Int. Energy Agency, 2013. [Online]. [Accessed: 01.02.2019] Available: https://cleanenergysolutions.org/sites/default/files/documents/2013-08-20-modernising-building-energy-codes.pdf

[2] Albatayneh A., Alterman D., Page A., Moghtaderi B. The significance of building design for the climate. Environmental and Climate Technologies 2018:22:165-178. doi:10.2478/rtuect-2018-0011

[3] Historical building types and combinations of structural solutions and main driving forces promoting renovation of historic buildings based on case studies. Report. EU project Robust Internal Thermal Insulation of Historic Buildings (RiBuild), project No. 637268: 2015.

[4] De Rosa M., Bianco V., Scarpa F., and Tagliafico L. A. Heating and cooling building energy demand evaluation; a simplified model and a modified degree days approach. Applied Energy 2014:128:217-229. doi:10.1016/j.apenergy.2014.04.067

[5] European Commission. Directive 2010/31/EU Of The European Parliament And Of The Council of 19 May 2010 on the energy performance of buildings (recast). Official Journal of the European Union 2010:153.

[6] Ratnieks J., Jakovics A., Gendelis S. Wall assemblies U-value calculation in test buildings using constant power heating. Energy Procedia 2018:147:207-213. doi:10.1016/j.egypro.2018.07.061

[7] Albatayneh A., Alterman D., Page A., Moghtaderi B. The Significance of Temperature Based Approach Over the Energy Based Approaches in the Buildings Thermal Assessment. Environmental and Climate Technologies 2017:19:39-50. doi:10.1515/rtuect-2017-0004 
[8] Franzoni E. Rising damp removal from historical masonries: A still open challenge. Constr. Build. Mater. 2014:54:123-136. doi:10.1016/j.conbuildmat.2013.12.054

[9] Krawczyk D. A., Wadolowska B. Analysis of indoor air parameters in an education building. Energy Procedia 2018:147:96-103. doi:10.1016/j.egypro.2018.07.038

[10] Jimenez-Bescos C., Prewett R. Monitoring IAQ and thermal comfort in a conservation area low energy retrofit. Energy Procedia 2018:147:195-201. doi:10.1016/j.egypro.2018.07.055

[11] Adhikari R., Lucchi E., Pracchi V. Experimental measurements on thermal transmittance of the opaque vertical walls in the historical buildings. PLEA2012 Conf. Oppor. Limits Needs Towar. an Environ. responsible Archit., 2012.

[12] Hola A. Measuring of the moisture content in brick walls of historical buildings - the overview of methods. IOP Conf. Ser. Mater. Sci. Eng. 2017:251:012067. doi:10.1088/1757-899X/251/1/012067

[13] Rosina E. When and how reducing moisture content for the conservation of historic building. A problem solving view or monitoring approach? J. Cult. Herit. 2018:31:S82-S88. doi:10.1016/j.culher.2018.03.023

[14] Barreira E., Almeida R. M. S. F., Delgado J. M. P. Q. Infrared thermography for assessing moisture related phenomena in building components. Constr. Build. Mater. 2016:110:251-269. doi:10.1016/j.conbuildmat.2016.02.026

[15] Jana seta [Online]. [Accessed 15.03.2019]. Available: https://www.kartes.lv/lv/

[16] Practice handbook for multifunction measuring meter T3000 (EN) [Online]. [Accessed: 01.02.2019] Available: https://uk.trotec.com/fileadmin/downloads/Multifunktion/T3000/TRT-PH-T3000-WM-001-EN.pdf

[17] LEGMC [Online]. [Accessed: 10.03.2019] Available: https://www.meteo.lv/
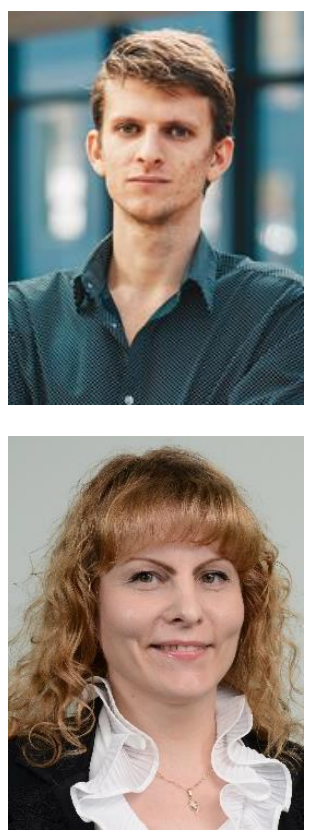

Rasa Vaiskunaite defended dissertation in the field of Technological Sciences (Environmental Engineering Sciences Field, 04T), Vilnius Gediminas Technical University (VGTU), 2004. Master of Natural Sciences (Ecology), Vilnius University (VU), 2000. Bachelor of Natural sciences (Biology), Vilnius Pedagogical University (VPU), 1998.

Work experience. Doctoral student (Ph. D.) of Technical Sciences (from 2000) in the Vilnius Gediminas Technical University (VGTU, formerly VTU); Assistant of the Environment Protection Department (from 2002) in VGTU; Associate Professor of the Environment Protection Department (from 2004) in the VGTU; Vice-Dean of the Environmental Engineering Faculty (from 2005) in VGTU; Professor of the Environment Protection and Water Engineering Department (from 2015) in VGTU.

Author prepared more than 73 scientific publications: 1 monograph, 1 handbook, 3 training books, 68 publications, 1 patent. Author participated in 16 conferences ( 7 of them international - in Sweden, Greece, Russia, Bulgaria etc.), Chairman of the Organizing Committee in 4 International Conferences "Environmental Engineering".

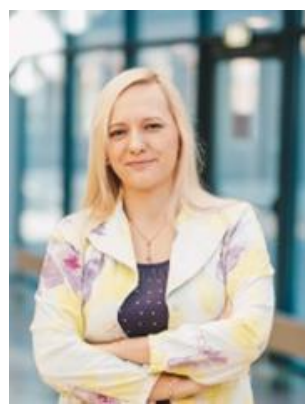

Tereza Bezrucko, Senior expert and project administrative manager at Riga Technical University, Institute of Energy Systems and Environment. Since 2008 Tereza Bezrucko is working at Riga Technical University. The main research area of the Author is analysis and planning of economic processes at local and international levels. She has been involved in more than $40 \mathrm{EU}$ and national research projects. 


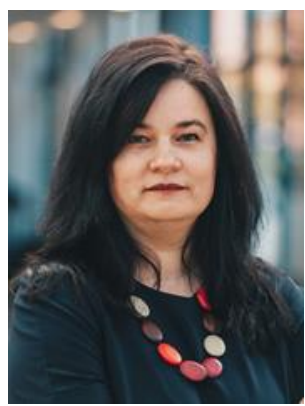

Andra Blumberga, Dr.sc.ing., professor, works for Institute of Energy Systems and Environments, Riga Technical University since 2001.

She has been working with energy efficiency since 1992. Her main research interest is energy efficiency both from technical and policy sides.

She has managed many national and international research and other projects since 1999, e.g. "Assessment on energy efficiency and use of renewable energy sources in Latvia by 2020", "Climate Technology development modelling in energy sector", "Energy strategy 2030 for Latvia", "System Dynamics modelling for energy sector in Latvia".

She has been working as the World Bank energy expert for development of the Green Investment Scheme in Latvia. She is author of more than 80 publications and 14 monographs. ORCID ID: https://orcid.org/0000-0002-4712-4794 